\title{
Hubungan Perdarahan Postpartum dengan Paritas di RSUP Dr. M. Djamil Periode 1 Januari 2010 - 31 Desember 2012
}

\author{
Nola Eriza ${ }^{1}$, Defrin$^{2}$, Yuniar Lestari ${ }^{3}$
}

\begin{abstract}
Abstrak
Penyebab utama kematian ibu di Indonesia adalah perdarahan (28\%), eklampsia (24\%) dan infeksi (11\%). Perdarahan postpartum merupakan penyebab tersering dari keseluruhan kematian akibat perdarahan obstetrik. Paritas merupakan salah satu faktor risiko untuk terjadinya perdarahan postpartum. Tujuan penelitian ini adalah menentukan hubungan perdarahan postpartum dengan paritas di RSUP Dr. M. Djamil Padang. Penelitian ini merupakan studi analitik menggunakan desain cross sectional study dengan cara mengambil data rekam medis pasien perdarahan postpartum di RSUP Dr. M. Djamil Padang periode 1 Januari 2010 sampai 31 Desember 2012, dengan jumlah 72 orang. Analisis statistik yang digunakan adalah uji chi-square dengan derajat kemaknaan 0,05. Hasil penelitian menunjukkan bahwa perdarahan postpartum terbanyak adalah perdarahan postpartum primer $(69,4 \%)$, paritas terbanyak adalah paritas $>3(37,5 \%)$. Pada uji statistik chi-square diperoleh $p=0,49(p>0,05)$ yang berarti secara statistik tidak terdapat perbedaan yang bermakna antara perdarahan postpartum primer dan sekunder dengan paritas. Walaupun tidak bermakna secara statistik, perdarahan postpartum meningkat seiring dengan peningkatan paritas. Saran kepada ibu hamil dengan paritas tinggi untuk secara rutin memeriksakan kehamilannya kepada petugas kesehatan agar kesehatan ibu dapat dikontrol dalam upaya mencegah perdarahan postpartum.
\end{abstract}

Kata kunci: perdarahan postpartum, paritas, kematian ibu

\section{Abstract}

The main causes of maternal mortality in Indonesia are hemorrhage (28\%), eclampsia (24\%) and infection (11\%). Postpartum hemorrhage is a common cause of all deaths due to obstetric hemorrhage. Parity is one of the risk factors for the occurrence of postpartum hemorrhage. The objective of this study was to determine the relationship between postpartum hemorrhage and parity at RSUP Dr. M. Djamil Padang. This research was analytic study using cross sectional study design by taking 72 medical record of postpartum hemorrhage at RSUP Dr. M. Djamil Padang within the period 1 January 2010 until 31 December 2012. The statistical analysis used was chi-square test with a significance level of 0,05 . The result showed that most of postpartum hemorrhage in this research is primary postpartum hemorrhage $(69,4 \%)$, the most parity is parity $>3(37,5 \%)$. Chi-square statistical test obtained $p=0,49$ ( $p>$ $0,05)$ which means there is no significant statistically between primary and secondary postpartum hemorrhage with parity. Although it's not significant statistically, postpartum hemorrhage was increase along with the increased of parity. It is suggested to pregnant women with risk factors of high parity to regularly check her pregnancy to health providers so that maternal health can be controlled in order to prevent primary postpartum hemorrhage.

Keywords: postpartum hemorrahage, parity, maternal mortality

Affiliasi penulis: 1. Pendidikan Dokter FK UNAND (Fakultas Kedokteran Universitas Andalas Padang), 2. Bagian Kebidanan FK UNAND/RSUP Dr. M Djamil Padang, 3. Bagian IImu Kesehatan Masyarakat FK UNAND.

Korespondensi: Nola Eriza, E-mail: Nola_aquariusgirl@yahoo.com, Telp: 085274066962

\section{PENDAHULUAN}

Derajat kesehatan masyarakat dapat dinilai dengan menggunakan beberapa indikator. Indikatorindikator tersebut pada umumnya tercermin dalam kondisi mortalitas, morbiditas, dan status gizi. Derajat 
kesehatan masyarakat di Indonesia digambarkan salah satunya melalui Angka Kematian Ibu (AKI). ${ }^{1}$

Angka Kematian lbu di Indonesia menurut

Survey Demografi dan Kesehatan Indonesia pada tahun 1997 dan 2002 sebesar 334 dan 307 per 100.000 kelahiran hidup. $^{2}$ Angka ini masih tinggi jika dibandingkan dengan negara-negara di Asia Tenggara yang rata-rata 5-142 per 100.000 kelahiran hidup. ${ }^{3} \mathrm{Di}$ Provinsi Sumatera Barat, AKI dalam 6 tahun terakhir cenderung menunjukkan penurunan, dari 240 per 100.000 kelahiran hidup tahun 2005 hingga 206 per 100.000 kelahiran hidup pada tahun $2010 .{ }^{4}$ Walaupun sudah mengalami penurunan AKI masih jauh dari target MDG's tahun 2015 yaitu untuk AKI 102 per 100.000 kelahiran hidup. $^{5}$

Perdarahan postpartum merupakan penyebab tersering dari keseluruhan kematian akibat perdarahan obstetrik. ${ }^{6}$ Perdarahan postpartum adalah perdarahan yang terjadi segera setelah partus (melahirkan), perdarahan yang melebihi $500 \mathrm{ml}$ setelah bayi lahir pada persalinan per vaginam dan melebihi $1000 \mathrm{ml}$ pada seksio sesarea, atau perdarahan yang lebih dari normal dan telah menyebabkan perubahan tanda vital (pasien mengeluh lemah, limbung, berkeringat dingin, menggigil, hiperpnea, sistolik $<90 \mathrm{mmHg}$, nadi> 100x/menit, kadar $\mathrm{Hb}<8 \mathrm{~g} \%) .^{6-9}$

Perdarahan postpartum diklasifikasikan berdasarkan waktu terjadinya yaitu perdarahan postpartum primer perdarahan apabila terjadi dalam waktu 24 jam setelah persalinan dan perdarahan postpartum sekunder apabila terjadi dalam waktu lebih dari 24 jam setelah persalinan. ${ }^{10,11}$ Kematian maternal lebih banyak terjadi dalam 24 jam pertama postpartum yang sebagian besar karena terlalu banyak mengeluarkan darah. ${ }^{12}$

Banyak faktor yang mempunyai arti penting dalam menimbulkan perdarahan postpartum, paritas merupakan salah satu faktor risiko untuk terjadinya perdarahan postpartum. Paritas adalah jumlah kehamilan yang menghasilkan janin yang mampu hidup diluar rahim/umur kehamilan 28 minggu. Wanita dengan paritas tinggi beresiko mengalami atonia uteri, yang apabila tidak ditangani dengan baik akan mengakibatkan perdarahan postpartum. ${ }^{6}$

Penelitian tentang hubungan paritas dengan perdarahan postpartum primer pernah dilakukan
Milaraswati tahun 2008 di Kediri dengan hasil terdapat hubungan yang signifikan antara paritas dengan perdarahan postpartum primer. ${ }^{13}$ Menurut penelitian Miswarti tahun 2007 di Padang dengan hasil ada hubungan perdarahan postpartum dini dengan paritas. $^{3}$

Kepustakaan terbaru tentang hubungan tersebut di RSUP Dr. M. Djamil Padang belum ditemukan, oleh karena itu tujuan penelitian ini adalah untuk mengetahui hubungan perdarahan postpartum dengan paritas di RSUP Dr. M. Djamil Padang Periode 1 Januari 2010 sampai 31 Desember 2012.

\section{METODE}

Penelitian dilaksanakan di RSUP Dr. M. Djamil Padang dari Januari 2013 sampai Maret 2013. Subjek penelitian adalah data rekam medik seluruh ibu bersalin di RSUP Dr. M. Djamil Padang yang mengalami perdarahan postpartum periode 1 Januari 2010 - 31 Desember 2012. Kriteria inklusi adalah data rekam medik seluruh ibu bersalin yang mengalami perdarahan postpartum. Kriteria eksklusi adalah data rekam medik pasien yang tidak lengkap sehubungan dengan data yang akan diambil, antara lain waktu perdarahan dan jumlah paritas yang tidak diketahui, pasien dengan penyakit kelainan pembekuan darah.

Metode penelitian yang digunakan adalah analitik dengan pendekatan cross sectional dengan mengumpulkan data kejadian masa lalu.

Data dianalisis dengan aplikasi komputer. Analisis data meliputi analisis univariat dan bivariat. Analisis univariat dilakukan terhadap tiap variabel untuk menghasilkan distribusi frekuensi dari masingmasing variabel tersebut. Analisis bivariat yang digunakan adalah chi-square dengan derajat kemaknaan 0,05 . Bila nilai $p \leq \alpha(0,05)$ berarti hasil perhitungan statistik bermakna (signifikan).

\section{HASIL}

Berdasarkan Tabel 1 dapat dilihat bahwa pada perdarahan postpartum primer dan perdarahan postpartum sekunder, paling banyak adalah penderita yang berumur 20-35 tahun yaitu 41 (82\%) pada perdarahan postpartum primer dan 14 (63,6\%) pada perdarahan postpartum sekunder. 
Tabel 1. Distribusi frekuensi umur penderita dengan perdarahan postpartum

\begin{tabular}{lcccc}
\hline Umur & \multicolumn{2}{c}{$\begin{array}{c}\text { Perdarahan } \\
\text { Postpartum Primer }\end{array}$} & \multicolumn{2}{c}{ Perdarahan } \\
& Postpartum Sekunder \\
\cline { 2 - 5 } & $\mathbf{f}$ & $\%$ & $\mathbf{f}$ & $\%$ \\
\hline$<20$ & 1 & 2 & 2 & 9,1 \\
$20-35$ & 41 & 82 & 14 & 63,6 \\
$>35$ & 8 & 16 & 6 & 27,3 \\
\hline Jumlah & 50 & 100 & 22 & 100 \\
\hline
\end{tabular}

\section{Perdarahan Postpartum}

Berdasarkan Tabel 2 dapat dilihat bahwa perdarahan postpartum partum yang paling banyak diderita adalah perdarahan postpartum primer yaitu sebanyak 50 orang $(69,4 \%)$.

Tabel 2. Distribusi frekuensi penderita perdarahan postpartum

\begin{tabular}{lll}
\hline \multicolumn{1}{c}{$\begin{array}{c}\text { Perdarahan } \\
\text { Postpartum }\end{array}$} & f & $\%$ \\
\hline Primer & & \\
Sekunder & 50 & 69,4 \\
\multicolumn{1}{c}{ Jumlah } & 22 & 30,6 \\
\hline
\end{tabular}

Paritas

Berdasarkan Tabel 3 dapat dilihat bahwa paritas penderita perdarahan postpartum terbanyak adalah paritas > 3 yaitu $27(37,5 \%)$ dengan rata-rata paritas penderita perdarahan postpartum adalah 2,97 $\pm 1,98$, paritas terendah 1 dan tertinggi 10 .

Tabel 3. Distribusi frekuensi perdarahan postpartum berdasarkan paritas

\begin{tabular}{ccccc}
\hline Paritas & $\mathbf{f}$ & $\%$ & Rerata & SD \\
\hline 1 & 22 & 30,6 & & \\
$2-3$ & 23 & 31,9 & 2,97 & 1,98 \\
$>3$ & 27 & 37,5 & & \\
\cline { 1 - 2 } Jumlah & 72 & 100 & & \\
\cline { 1 - 3 } & & & & \\
\hline
\end{tabular}

Berdasarkan Tabel 4 dapat dilihat bahwa paritas terbanyak pada perdarahan postpartum primer adalah paritas > $3(42 \%)$, sedangkan paritas terbanyak pada perdarahan postpartum sekunder adalah paritas 1, 2 dan $3(36,4 \%)$.
Tabel 4. Distribusi frekuensi perdarahan postpartum berdasarkan jumlah paritas

\begin{tabular}{lcccc}
\hline Paritas & \multicolumn{2}{c}{$\begin{array}{l}\text { Perdarahan } \\
\text { Postpartum } \\
\text { Primer }\end{array}$} & \multicolumn{3}{c}{$\begin{array}{l}\text { Perdarahan } \\
\text { Postpartum } \\
\text { Sekunder }\end{array}$} \\
\cline { 2 - 5 } & $\mathbf{f}$ & $\%$ & $\mathbf{f}$ & $\%$ \\
\hline 1 & 14 & 28 & 8 & 36,4 \\
$2-3$ & 15 & 30 & 8 & 36,4 \\
$>3$ & 21 & 42 & 6 & 27,3 \\
\hline Jumlah & 50 & 100 & 22 & 100 \\
\hline
\end{tabular}

Berdasarkan Tabel 5 dapat dilihat bahwa persentase perdarahan postpartum primer lebih besar pada paritas > 3 dibandingkan paritas 1 dan 2-3. Sedangkan persentase perdarahan postpartum sekunder lebih besar pada paritas 1 dibandingkan paritas 2-3 dan > 3. Hasil uji statistik dengan menggunakan chi square, diperoleh nilai $p=0,49(p>$ $0,05)$, artinya secara statistik tidak terdapat perbedaan yang bermakna antara perdarahan postpartum primer dan sekunder dengan paritas.

Tabel 5. Hubungan perdarahan postpartum dengan paritas

\begin{tabular}{|c|c|c|c|c|c|c|c|}
\hline \multirow{3}{*}{ Paritas } & \multicolumn{4}{|c|}{ Perdarahan Postpartum } & \multirow{2}{*}{\multicolumn{2}{|c|}{ Total }} & \multirow{3}{*}{$\mathbf{p}$} \\
\hline & \multicolumn{2}{|c|}{ Primer } & \multicolumn{2}{|c|}{ Sekunder } & & & \\
\hline & $f$ & $\%$ & $f$ & $\%$ & f & $\%$ & \\
\hline 1 & 14 & 63,6 & 8 & 36,4 & 22 & 100 & \multirow{4}{*}{0,49} \\
\hline $2-3$ & 15 & 65,2 & 8 & 34,8 & 23 & 100 & \\
\hline$>3$ & 21 & 77,8 & 6 & 22,2 & 27 & 100 & \\
\hline Jumlah & 50 & & 22 & & 72 & & \\
\hline
\end{tabular}

\section{PEMBAHASAN}

\section{Perdarahan Postpartum}

Pada Tabel 2 dapat dilihat bahwa persentase perdarahan postpartum primer lebih besar dari perdarahan postpartum sekunder(69,4\% : 30,6 \%). Hasil penelitian ini sesuai dengan penelitian Sulistiyani tahun 2010 di RS Panti Wilasa Dr.Cipto Semarang yang menunjukkan bahwa persentase perdarahan postpartum primer lebih besar dari perdarahan postpartum sekunder (58,8\%: 41, 2\%). ${ }^{14}$ Penelitian 
Rukmini tahun 2007 di RSUD Pesisir Selatan, RSUD Padang Pariaman, RSUD Sikka, RSUD Larantuka dan RSUD Serang yang menunjukkan bahwa perbandingan persentase perdarahan postpartum primer dan perdarahan postpartum sekunder ( $83,3 \%$ : $16,7 \%) .{ }^{15}$

Perdarahan postpartum primer dapat disebabkan oleh atonia uteri yang mengakibatkan uterus tidak mampu menutup perdarahan terbuka dari tempat implantasi plasenta setelah bayi dan plasenta lahir sehingga terjadi perdarahan postpartum primer. Kemudian plasenta yang tetap tertinggal dalam uterus setengah jam setelah anak lahir juga dapat mengakibatkan perdarahan postpartum primer, penyebab lain adalah robekan jalan lahir dan gangguan pembekuan darah. ${ }^{16}$

Penanganan retensio plasenta sebagai penyebab perdarahan postpartum primer yang tidak tuntas, seperti tidak memeriksa kelengkapan plasenta yang dikeluarkan dapat mengakibatkan perdarahan postpartum sekunder. Hal ini disebabkan oleh adanya sisa plasenta di dalam uterus. Biasanya bagian plasenta yang tertinggal mengalami nekrosis tanpa deposit fibrin dan pada akhirnya membentuk polip plasenta. Apabila serpihan polip plasenta terlepas dari miometrium, perdarahan dapat terjadi. ${ }^{6}$ Selain itu luka robekan jalan lahir yang terbuka kembali juga dapat menyebabkan perdarahan postpartum sekunder. ${ }^{11}$

Penanganan terbaik perdarahan postpartum adalah pencegahan. Tindakan pencegahan tidak saja dilakukan sewaktu bersalin, namun sudah dimulai sejak wanita hamil dengan antenatal care yang baik. Pengawasan antenatal memberikan manfaat dengan ditemukannya berbagai kelainan secara dini, sehingga dapat diperhitungkan dan dipersiapkan langkahlangkah dalam pertolongan persalinannya. Kunjungan pelayanan antenatal bagi ibu hamil paling sedikit 4 kali kunjungan dengan distribusi sekali pada trimester I, sekali trimester II, dan dua kali pada trimester III. ${ }^{18}$

Hasil penelitian di RSUP M. Djamil Padang ini menunjukkan perdarahan postpartum primer lebih banyak terjadi daripada perdarahan postpartum sekunder dan tidak ditemukan perdarahan postpartum sekunder sebagai akibat dari penanganan perdarahan postpartum primer yang tidak tuntas. Kemungkinan penanganan perdarahan postpartum primer sudah baik, sehingga perdarahan postpartum sekunder dapat dihindari.

\section{Paritas}

Pada Tabel 3 dapat dilihat bahwa paritas penderita perdarahan postpartum terbanyak adalah > 3 yaitu $37,5 \%$. Hal ini sesuai dengan penelitian Miswarti pada tahun 2007 bahwa angka kejadian paritas 1 sebanyak 11,54\%, paritas 2-3 sebanyak $40 \%$ sedangkan paritas besar sama empat lebih tinggi dibandingkan paritas 2-3 yaitu sebanyak 48,46\%. ${ }^{3}$ Paritas adalah jumlah persalinan yang melahirkan bayi dengan usia kehamilan mencapai 28 minggu atau lebih. Paritas diklasifikasikan menjadi nullipara, primipara (paritas 1), multipara (paritas 2 dan 3), dan grandemultipara (paritas $>3$ ). ${ }^{8}$

Pada Tabel 4 dapat dilihat bahwa paritas terbanyak pada perdarahan postpartum primer adalah paritas > 3 (42\%), hal ini sesuai dengan yang dikemukakan Cunningham pada tahun 2005 bahwa wanita dengan paritas tinggi $(\geq 4)$ menghadapi resiko perdarahan akibat atonia uteri yang semakin meningkat sehingga dapat menyebabkan perdarahan postpartum primer. ${ }^{6}$

Paritas penderita perdarahan postpartum sekunder terbanyak terjadi pada paritas 1,2 , dan 3 $(36,4 \%)$. Hal ini tidak sesuai dengan yang dikemukakan Karkata pada tahun 2008 bahwa paritas tinggi dapat memicu tertinggalnya sebagian jaringan plasenta di uterus dan dapat menyebabkan perdarahan postpartum sekunder. ${ }^{16}$ Tingginya persentase perdarahan postpartum sekunder pada paritas 1, 2, dan 3 kemungkinan dipengaruhi oleh faktor lain seperti umur, jarak antar kelahiran yang pendek, riwayat persalinan buruk sebelumnya, dan anemia.

\section{Hubungan Perdarahan Postpartum dengan Paritas}

Pada Tabel 5 didapatkan nilai $p=0,49$ yaitu $p$ $>\alpha(\alpha=0.05)$, berdasarkan hasil tersebut, dapat disimpulkan paritas tidak signifikan mempengaruhi perdarahan postpartum. Penelitian ini sesuai dengan penelitian Lubis tahun 2011 di Rumah Sakit Umum Dr. Pirngadi Medan yang menyatakan bahwa paritas tidak signifikan mempengaruhi perdarahan postpartum primer. ${ }^{19}$ Hasil penelitian Badriyah et al tahun 2011 di 
RSUD Syarifah Ambami Rato Ebu Bangkalan menyatakan tidak ada pengaruh paritas terhadap terjadinya perdarahan postpartum. ${ }^{20}$ Kemudian penelitian Pardosi tahun 2006 di Wilayah Kerja Puskesmas Kota Medan juga menunjukkan paritas tidak bermakna mempengaruhi perdarahan postpartum. $^{21}$

Pada penelitian di RSUP Dr. M. Djamil tahun 2013 ini, menunjukkan bahwa persentase paritas ibu yang mengalami perdarahan postpartum dengan paritas 1 sebesar $30,6 \%$, paritas 2 dan 3 sebesar $31,9 \%$, dan paritas $>3$ sebesar $37,5 \%$. Hal ini menunjukkan meskipun tidak bermakna secara statistik, perdarahan postpartum meningkat seiring dengan peningkatan paritas dan sesuai dengan yang dikemukakan Cunningham pada tahun 2005 bahwa paritas tinggi merupakan salah satu faktor risiko untuk terjadinya perdarahan postpartum. ${ }^{6}$

Paritas tinggi mempengaruhi keadaan uterus ibu, karena semakin sering ibu melahirkan maka uterus cenderung bekerja tidak efisien dalam semua kala persalinan sehingga menimbulkan kegagalan kompresi pada tempat implantasi plasenta akibatnya terjadi perdarahan postpartum primer. ${ }^{6}$ Selain itu, paritas tinggi dapat memicu tertinggalnya sebagian jaringan plasenta di uterus dan dapat menyebabkan perdarahan postpartum sekunder. ${ }^{16}$

Penelitian di RSUP Dr. M. Djamil tahun 2013 ini berbeda dengan penelitian Sulistiyani pada tahun 2010 di Rumah Sakit Panti Wilasa Dr Cipto Yakkum Cabang Semarang yang menunjukkan ada hubungan antara paritas dengan perdarahan postpartum. ${ }^{14}$ Hasil penelitian Milaraswati tahun 2008 di RSUD Gambiran Kota Kediri, Miswarti tahun 2007 di RSUP Dr. M. Djamil Padang, dan Herianto tahun 2003 di RS Sardjito Yogyakarta menyatakan bahwa ada hubungan yang signifikan antara paritas dengan perdarahan postpartum primer. ${ }^{3,13,22}$

Paritas tidak bermakna secara statistik mempengaruhi perdarahan postpartum kemungkinan disebabkan oleh beberapa hal, pertama faktor ibu yang sudah menerapkan antenatal care secara baik selama kehamilan, sehingga dapat diketahui kondisi kesehatan ibu dan dapat dipersiapkan langkahlangkah dalam pertolongan persalinan yang aman dari perdarahan postpartum walaupun terhadap ibu dengan paritas tinggi. Kedua, Menurut Karkata pada tahun 2008 apabila dalam pertolongan persalinan diberikan uterotonika segera setelah persalinan bayi sehingga persalinan plasenta lebih cepat dan terjadi kontraksi uterus, maka perdarahan postpartum tidak akan terjadi. ${ }^{16}$ Ketiga, perdarahan postpartum dapat dipengaruhi oleh lebih dari 1 faktor. Selain paritas, perdarahan postpartum dapat dipengaruhi oleh umur, jarak kehamilan yang pendek, riwayat persalinan buruk sebelumnya, dan anemia.

Pada Tabel 1 dapat dilihat bahwa dari 72 data perdarahan postpartum didapatkan kelompok umur terbanyak adalah $20-35$ (59,7\%) dengan rata-rata umur 31 tahun. Hal ini tidak sesuai dengan yang diungkapkan Wiknjosastro pada tahun 2005 bahwa wanita yang melahirkan pada usia di bawah 20 tahun atau lebih dari 35 tahun merupakan faktor risiko terjadinya perdarahan pasca persalinan yang dapat mengakibatkan kematian maternal. Pada usia di bawah 20 tahun fungsi reproduksi seorang wanita belum berkembang dengan sempurna, sedangkan pada usia diatas 35 tahun terjadi kemunduran yang progresif dari endometrium, hal ini berpengaruh terhadap kekuatan kontraksi pada saat persalinan dan setelah persalinan. ${ }^{23}$

Hasil penelitian di RSUP Dr. M. Djamil Padang ini berbeda dengan penelitian Suryani pada tahun 2008 di Rumah Sakit Umum Dr. Pirngadi Medan dan Sulistiyani pada tahun 2010 di Rumah sakit Panti Wilasa Dr Cipto Yakkum Cabang Semarang yang menyatakan bahwa risiko untuk mengalami perdarahan postpartum pada kelompok umur $<20$ tahun dan > 35 tahun lebih besar dibandingkan dengan kelompok umur antara 20-35 tahun. ${ }^{14,18}$ Perbedaan ini dapat terjadi apabila ada faktor lain yang menyebabkan perdarahan postpartum walaupun umur ibu berada pada umur yang dikategorikan aman dari segi terjadinya perdarahan postpartum. Selain itu, jumlah persalinan terbanyak terjadi pada umur 20-35 tahun (usia reproduktif) sehingga kemungkinan terjadi perdarahan postpartum juga paling banyak pada umur tersebut.

\section{KESIMPULAN}

Distribusi frekuensi penderita perdarahan postpartum terbanyak adalah perdarahan postpartum 
primer. Distribusi frekuensi paritas penderita perdarahan postpartum terbanyak adalah paritas $>3$ (grandemultipara). Distribusi frekuensi paritas perdarahan postpartum primer terbanyak adalah paritas > 3 sedangkan pada perdarahan postpartum sekunder adalah paritas 1 (primipara) dan 2- 3 (multipara).

Berdasarkan analisis bivariat paritas tidak signifikan mempengaruhi perdarahan postpartum. Meskipun tidak bermakna secara statistik, perdarahan postpartum meningkat seiring dengan peningkatan paritas.

\section{DAFTAR PUSTAKA}

1. Departemen Kesehatan Republik Indonesia. Profil kesehatan Indonesia 2010. Jakarta: Kementrian Kesehatan Republik Indonesia; 2011.

2. PP dan KPA (Pemberdayaan Perempuan dan Komisi Perlindungan Anak). Angka kematian ibu melahirkan. 2010 (diunduh 21 Februari 2012). Tersedia dari: URL: HYPERLINK http://www. menegpp.go.id

3. Miswarti. Hubungan kejadian perdarahan postpartum dini dengan paritas di RSUP Dr. M. Djamil Padang tahun 2005. Jurnal Kesehatan Masyarakat. 2(1):133-5.

4. Dinkes Provinsi Sumatera Barat. Profil kesehatan Provinsi Sumatera Barat 2009. Padang. 2010.

5. Kemenkes RI. Rencana Strategis Kementrian Kesehatan tahun 2010-2014. Jakarta. 2010.

6. Cunningham FG. Obstetri Williams. Edisi ke-21. Jakarta: EGC; 2005.

7. Dorland WA, Newman. Kamus kedokteran Dorland . Edisi ke-29. Jakarta: EGC; 2002.

8. Prawirohardjo S. IImu kebidanan. Edisi ke-4. Jakarta: PT Bina Pustaka Sarwono Prawirohardjo; 2008.

9. Saifuddin $A B$. Buku panduan praktis pelayanan kesehatan maternal dan neonatal. Edisi ke-1. Jakarta: Yayasan BINA Pustaka Sarwono Prawirohardjo; 2002.

10. Llewellyn J. Dasar-dasar obstetri \& ginekologi. Edisi ke-6. Jakarta: Hipokrates; 2001.

11. Coker A, Oliver R. Definition and classifications. Dalam: Lynch B, Christopher, Louis G, Keith. Andre B. Lalonde, Mahantesh $\mathrm{K}$, editor (penyunting). A textbook Of Postpartum Hemorrhage. UK; 2006. hlm. 11-2.

12. Halimah, Rahmadhani R. Konsep perdarahan postpartum. 2012 (diunduh 11 Februari 2013). Tersedia dari: URL: HYPERLINK http://ilmu kebidananstikeskendedesmalang.blogspot.com/20 12/11/01/paritas.html

13. Milaraswati D. Hubungan antara paritas dengan kejadian perdarahan postpartum primer di kamar bersalin RSUD Gambiran Kota Kediri periode 1 Januari - 31 Desember 2007. Malang: Karya Tulis ilmiah Politeknik Kesehatan Depkes Malang; 2008.

14. Sulistiyani $\mathrm{CN}$. Hubungan antara paritas dan umur ibu dengan kejadian postpartum di RS Panti Wilasa "Dr. Cipto" Yakkum Cabang Semarang. J. Keperawatan dan Kebidanan (JIKK). 2010;2(1): 94-102.

15. Rukmini WLK. Gambaran penyebab kematian maternal di rumah sakit (Studi di RSUD Pesisir Selatan, RSUD Padang Pariaman, RSUD Sikka, RSUD Larantuka dan RSUD Serang 2005). CKD. 2007;(34)5:158.

16. Karkata MK. Perdarahan postpartum (PPP). Dalam: Saifuddin, Abdul B, Trijatmo R, Gulardi H, Wiknjosastro, editor (penyunting) Edisi ke-4, Jakarta: PT Bina Pustaka Sarwono Prawirohardjo; 2008.

17. Norwitz ER, Schorge JO. At a glance obstetri \& ginekologi. Jakarta: Erlangga; 2007.

18. Suryani. Hubungan karakteristik ibu bersalin dan antenatal care dengan perdarahan pasca persalinan di Rumah Sakit Umum Dr. Pirngadi tahun 2007 (tesis). Medan: Universitas Sumatera Utara; 2008.

19. Lubis IK. Pengaruh paritas terhadap perdarahan postpartum primer di RSUD Dr. Pirngadi Medan 2007-2010 (skripsi). Medan: Universitas Sumatera Utara; 2011.

20. Badriyah, Sulastri, Rahardjo S. Pengaruh faktor resiko terhadap perdarahan ibu postpartum di RS Syarifah Ambami Rato Ebu Bangkalan. Jurnal Penelitian Kesehatan Suara Forikes. 2011:II(1): 32-6.

21. Pardosi M. Analisis faktor-faktor yang berhubungan dengan perdarahan pasca persalinan dan upaya penurunannya di wilayah kerja Puskesmas Kota 
Medan tahun 2005. Jurnal Ilmiah PANNMED. 2006:1(1): 29-37.

22. Herianto $A B$. Analisis faktor yang mempengaruhi perdarahan postpartum dini di RS Sardjito
Yogyakarta (tesis). Yogyakarta: Universitas Gajah Mada; 2003.

23. Wiknjosastro $H$. Ilmu bedah kebidanan. Jakarta: Yayasan Bina Pustaka Sarwono Prawirohardjo; 2005. 